\title{
Opportunity Identification and Creation as Factors of Firm Internationalisation
}

\author{
Agnieszka Żur
}

\section{A B S T R A C T}

Objective: This paper aims to establish if, why and how, in given institutional and industry contexts, the identification and/or creation and exploitation of opportunity may result in a higher intensity of internationalisation processes in firms.

Research Design \& Methods: The study is based on literature review. It synthesizes fragmented pieces of research on international entrepreneurship, mainstream entrepreneurship and entrepreneurial learning theory. In-depth comparative literature studies focus on sources, forms and features of opportunities, as well as the role of both Schumpeterian and Kirznerian opportunities in internationalisation activities of firms.

Findings: Findings bring together state-of-the-art research and extends it by providing a deeper understanding of the feed-back effect of entrepreneurial learning as well as highlighting the progressive nature of opportunity space in the proposed model.

Implications \& Recommendations: Expanding firm's operations can be a first step towards a self-reinforcing loop relationship, tying prior experience to future behaviour and moving the entrepreneur to higher levels of international awareness and accuracy in opportunity identification.

Contribution \& Value Added: The article presents an integrated process-based view of opportunity antecedents and concludes with a dynamic cyclical path-dependent model of opportunity-based view of firm internationalisation. Hopefully, the proposed model can serve as a useful lens for hypotheses formulation and testing within the research on firm internationalisation determinants.

\section{Article type: conceptual article}

Keywords:

opportunity identification; opportunity recognition; opportunity

JEL codes: creation; international entrepreneurship; internationalisation

\section{Suggested citation:}

Żur, A. (2015). Opportunity Identification and Creation as Factors of Firm Internationalisation. Entrepreneurial Business and Economics Review, 3(2), 25-39. doi: 10.15678/EBER.2015.030203 


\section{INTRODUCTION}

Internationalisation in its broad sense refers to the cross border flow of products, services, people, money, information, ideas and more. As such, firm internationalisation encompasses all economic expansion activities undertaken by firms abroad (Pierścionek, 2011, p. 359). Firm internationalisation remains a topic of strong interest to both academic and management circles. Conceptualizing internationalisation, Welch and Luostarinen (1988) emphasize the process through which firms get increasingly involved in international markets. Authors outline two main groups of factors responsible for firm internationalisation: push factors associated with shortage of opportunity in the domestic market and pull factors associated with potential opportunities on foreign markets. Both of these refer to opportunity as central issue. The notion of opportunity creation, recognition and exploitation are traditionally associated with entrepreneurship. Yet, according to some authors, the development of activity in foreign markets, regardless the form, is an entrepreneurial act per se, since it consists of exploiting new risk-related opportunities in new environments (Lu \& Beamish, 2001; Ripolles-Melia et al., 2007). This study is based on that assumption.

This study takes the entrepreneurial opportunity lens to internationalisation processes of firms for three reasons. First, understanding the nature of opportunities in international contexts is important because it can enhance firm's performance. Research has shown that some industries and/or geographic regions produce more opportunities than other measured by the number of startups (Shane, 2003). This phenomenon cannot be explained by an individual-centric approach as there is no evidence of wide swings in the allocation of entrepreneurial individuals across countries or industries. The logical explanation turns our attention to a relatively higher amount of business opportunities in certain countries and industries. Simply put, some countries may present more fertile grounds in terms of opportunity than others. Recognizing that phenomena can optimize internationalisation processes of firms. Therefore opportunity as unit of analysis is much advised.

Second, authors have noted that research focused strictly on the firm, may be useful for some domains such as strategic entrepreneurship which compares performance between competitive firms, but it does not add enough insight into the entrepreneurship nexus (Shane \& Venkataraman, 2000). Performance advantage over other firms is not a sufficient measure of entrepreneurship, since entrepreneurship is concerned with discovery and exploitation of profitable opportunities. Opportunity as unit of analysis in entrepreneurship research allows the assessment of entrepreneurial acts and provides a deeper understanding of its dynamics. Firm internationalisation as entrepreneurial act is always a response to perceived opportunity and therefore requires an opportunity-based approach as well.

Third, the paper addresses a call made by Zahra and Wright (2011) that research needs to move beyond filling in the potholes in a well-known path. These authors suggest the need for "creative reconstruction" in the field that will bring about a shift in research focus (Zahra \& Wright, 2011, p. 69). Examining the role of opportunity in internationalisation processes is a response to that call. Authors have signalled that there is an important area for research in the conceptual gap between innovation and markets, 
which can be filled by the notion of entrepreneurial opportunity (Sarasvathy et al., 2010, p. 78). Internationalisation as response to opportunity requires advancement, since as some authors claim: "the opportunity side of internationalisation process is not very well developed" (Chandra et al., 2012, p. 75).

The main goal of this paper is to present a model of opportunity-based view (OBV) of firm internationalisation which can hopefully serve as research framework. The article synthesizes the antecedents and conceptualizations of this stream of theory, claiming that OBV provides a useful lens for international business activity analysis. The paper starts with introducing opportunity as a unit of analysis, and then it explores the antecedents of opportunity development to sum up with a proposal of a research model. The major contribution of this study lies in extending the existing body of firm internationalisation research and providing a new perspective, placing opportunity and its cyclical nature, in the centre of the discussion.

\section{MATERIAL AND METHODS}

The preliminary literature review and established objectives of the study led to prepare a conceptual framework based on extensive and critical literature review in line with the deductive process. The study synthesizes fragmented pieces of research on international entrepreneurship, mainstream entrepreneurship and entrepreneurial learning theory. In recent decades entrepreneurship theory has grown in scope, developed and split into many sub-streams.

Within recent developments in entrepreneurship theory, entrepreneurial opportunity emerges as a key notion of the entrepreneurial process. This study relies on opportunity as a unit of research and explores the dynamics of opportunity recognition. In-depth comparative literature studies focus on sources, forms and features of opportunities, as well as the role of both Schumpeterian and Kirznerian opportunities in internationalisation activities of firms. On top, it refers to entrepreneurial learning theory as a necessary prism for exploration of internationalisation reinforcement and accuracy in international opportunity exploitation.

The aim of the research is to identify the antecedents of opportunity in firm internationalisation context and, consequently, to propose an integrated model of opportunity-based view of firm internationalisation. The deductive approach provides structure, logic and leads to research results.

\section{LIREATURE REVIEW AND THEORY DEVELOPMENT}

\section{Opportunity as a Unit of Analysis}

Opportunity is referred to as the dominant thread in current mainstream entrepreneurship research, both individual- and firm-level (Venkataram et al., 2012). According to Stevenson and Jarillo-Mossi (1986) the pursuit of opportunity, defines the ability of the individual, as well as the organization to be entrepreneurial. Contemporary coexisting convictions regarding entrepreneurship are rather completing than competing, all referring to the identification, evaluation and pursuit of opportunity (Stevenson \& Jarillo-Mossi, 1986; Jones \& Butler, 1992; Shane \& Venkataram, 2000). 
Early conceptualisations of opportunity define them as situations in which new goods, services, raw materials and organizing methods can be introduced and sold at greater price than their cost of production process (Casson, 1982). As Schumpeter (1934) elaborated, economies operate in a constant state of disequilibrium. Technological, political, social, regulatory, and other types of changes offer a continuous supply of new information about different ways to use resources and create wealth. By making it possible to transform resources into a more valuable form, new information can alter the value of resources and, therefore, the resources' proper equilibrium price. Because information is imperfectly distributed, all players in the market do not simultaneously acquire new information. Some players obtain information before others about resources lying fallow, new discoveries being made, or new markets being created. Those that obtain new information before others can purchase resources at below their equilibrium value and earn an entrepreneurial profit by recombining the resources and then selling them (Schumpeter, 1934). This suggests that time is an important aspects of opportunity exploitations and that early movers are more likely to succeed.

Taken these early findings, opportunities can come in various forms, yet their prerequisite is information asymmetry. Authors still disagree whether opportunities are objective or subjective phenomena. Shane and Venkataram (2000) argue that, although the recognition of opportunity is a subjective process, opportunities themselves are objective phenomena that are not known to all people at all times. An opposing argument developed by others suggests that opportunities may be also created rather than discovered ( $\mathrm{Li}, 2013)$. Opportunity creation may be driven by subjective beliefs and actions, rather than objective factors. According to some, these are human beings who bring life and meaning to opportunities, as without them opportunities are non-existent. Both positions hold strong arguments in this discussion and might be completing rather than competing, taken the vast array of opportunity sources.

Drucker (1985) depicted three basic sources of opportunities: (i) the creation of new knowledge, usually as a result of technological progress; (ii) market inefficiencies that result from information asymmetry across time and space; and (iii) shifts in the relative costs and benefits of resources resulting from political, regulatory or demographic changes. All of the above sources of opportunity refer directly to business internationalisation. The first case represents a situation when opportunity occurs due to industry specific developments. Technology and new knowledge inefficiencies in some countries can produce high demand for certain goods and offer profitable opportunities for foreign entrepreneurs. Secondly, information asymmetry can occur across geography. This can be related, for example, to weak capital market or institutional structures in developing economies. Information gaps can present an opportunity for foreign entrepreneurs and stimulate them to compete in environments where they hold the advantage of superior access to information. Thirdly, opportunities for internationalisation often occur due to political or regulatory shifts. Institutional or legal transitions, such as privatization processes in post-communist countries offered numerous opportunities for outside investors. Authors have established two other important factors (sources) of international venture opportunities, which do not fall directly into Drucker's classification: cost of capital and cost of labour (Li, 2013). Last 
decades have provided numerous examples of entrepreneurial opportunities associated with low labour costs.

Shane (2003) offers a different typology of opportunities, based on whether they rely on completely new combinations of means-ends or optimize existing ones. He refers to those two situations as to Schumpeterian and Kirznerian opportunities respectively. This distinction has been followed in later years by other authors and researchers have established that these two perspectives explain to existence of different types of opportunities that can be both present in an economy at the same time (Shane \& Venkataraman, 2000), yet they may have different effects on the economic activity of the entrepreneur and bear different effects on the economy.

Schumpeterian opportunities result from disequilibrating forces and result in disrupting the existing system (Table 1). They break away from existing knowledge and rely primarily on new knowledge and innovative ideas. Schumpeterian opportunities make the accumulation of evidence for their value and duration difficult. As a result, they are more risk sensitive and represent high profit potential (Aldrich, 1999). Kirznerian opportunities, on the other hand, result from equilibrating forces and bring the economy closer to equilibrium. They rely on existing information and often replicate exiting organizational forms and established ways of doing things (Shane, 2003). Kirznerian opportunities emerge because prior market players made errors or omissions that have created surpluses or shortages. As such they are idiosyncratic, characteristic to an individual market situation (Shane, 2003) and thus, Kirznerian opportunities are rather identified than created and involve observation and analytical skills in pursue of profit.

Table 1. Shane's Perspective on Schumpeterian and Kirznerian opportunities

\begin{tabular}{|l|l|}
\hline Schumpeterian opportunities & Kirznerian opportunities \\
\hline $\begin{array}{l}\text { Take advantage of disequilibrating } \\
\text { economic/market forces }\end{array}$ & Take advantage of information asymmetry \\
\hline Create new combinations of means-ends & Optimize existing combinations of means-ends \\
\hline Rely primarily on new knowledge & Rely primarily on existing knowledge \\
\hline Involve imagination and creativity & Involve observation and critical analysis \\
\hline Rather created than identified & Rather identified than created \\
\hline Objectively innovating & Rather replicating \\
\hline Rather rare & Numerous \\
\hline Rather risk sensitive & Rather risk averse \\
\hline Result in disrupting the existing equilibrium & Bring the economy closer to equilibrium \\
\hline
\end{tabular}

Source: own study based on Schumpeter (1934), Kirzner (1973) and Shane (2003).

\section{Features of Opportunities}

All opportunities, despite their type and source have two important features: value and longevity (Shane, 2003). The value of opportunity is expressed in the belief that its expected profit will be larger than the cost of other alternatives (Kirzner, 1997). Again, opportunity value is not an objective phenomenon as it is based on subjective judgment and refers to the future. Because the range of options and the consequences of exploiting new opportunities are unknown, internationalisation decisions cannot be made uniquely through an optimization process in which mechanical calculations are 
made in response to a given set of alternatives. Even if two entrepreneurs might both identify an opportunity for internationalisation, they are very likely to give that opportunity different value. Kirzner (1973) observed that the process of discovery of opportunities requires entrepreneurs to assess customers' expectations about a variety of things, such as accepted level of price, quality or other product attributes. People make decisions on objective as well as subjective basis, often difficult or impossible to measure. Judging these expectations is therefore a highly subjective process.

Another feature of opportunities is their limited duration. Because entrepreneurial opportunities depend on asymmetries of information and beliefs, eventually, they become less profitable or even cost inefficient to pursue. This is for two prime reasons. First, as opportunities are exploited, information diffuses to other members of society who can imitate the entrepreneur and competition increases. Firms that enter foreign markets and generate high profits are usually followed by other entrants. When the entry rate of additional entrepreneurs reaches a level at which the benefits from new entrants exceeds the cost, the incentive for people to pursue the opportunity is reduced, as observed early on by Schumpeter (1934). Second, the exploitation of opportunity provides information to resources providers about the value of the resources that they possess and leads them to raise resource prices over time, in order to capture some profit (Kirzner, 1997).

The aspect of opportunity value and its decrease over time has important implications for firms which operate internationally. Some authors suggest that internationalisation speed plays a fundamental role in the long-term growth of firms (Autio et al., 2000). The notion of speed in internationalisation theory primarily refers to the time elapsing between the company's foundation and its first international entry, and secondly to the pace of subsequent international growth (Casillas \& Acedo, 2013). Results in this stream of research suggests that the speed variable helps to explain successful ways of achieving superior performance on the international arena and has prompted a body of work relating to firms that internationalize rapidly, the born-globals. Studies have shown that born-globals break the pattern of gradual internationalisation, since their internationalisation decisions are determined by the perceived opportunity, its current value and remaining durability. Internationalisation as response to opportunity occurs in various modes, following the opportunity-based contingency approach (Chandra et al., 2012), regardless whether the market is in close physical distance. This suggests that some firms realize the limited duration and declining value of opportunity in international contexts.

Taking all of the above into consideration, opportunities in firm internationalisation context can be defined as situations in which new mean-ends combinations in international environments can be created or optimized and that hold value over a limited amount of time.

The study of internationalisation through opportunity lens is referred to as an opportunity-based view (OBV) of internationalisation and conceptualizes firm internationalisation as "the behavioral processes associated with the creation and exchange of value through the identification and exploitation of opportunities that cross national borders" (Chandra et al., 2012, p. 75). In the context of firm internationalisation both information and individual cognitive properties refer to an international context. 
Opportunity-based view refers to pull factors of internationalisation, that are situations in which firms identify or create a business opportunity abroad (Daszkiewicz \& Wach, 2012, p.15; 2014, p. 7) and should be considered entrepreneurial internationalisation, which is aligned with the concept of international entrepreneurship (Wach \& Wherman, 2014, p. 15). This approach encourages researchers to go beyond the focus on the firm or the entrepreneur and adapt a holistic view of opportunity related behaviours. Authors note that exploration and development of opportunities go beyond the immediate organizational context and that considerable insight can be gained by examining the history, emergence and exploitation of opportunities in internationalisation acts (Styles \& Seymore, 2006; Chandra et al., 2012). OBV perspective adapts a process-oriented approach to internationalisation, in which antecedents of opportunity, path dependence and feedback effects are all relevant to our understanding of opportunity dynamics.

\section{Antecedents of Opportunity in Firm Internationalisation Context}

It has been asserted in the past that two prime factors influence the probability that people identify and exploit opportunities: the possession of necessary information and cognitive properties of individuals (Shane \& Venkataraman, 2000; Shane, 2003; Mitchell et al., 2002).

It has been established by OBV of internationalisation literature that possession of necessary information can be impaired most by the entrepreneur's prior knowledge and experience and his social networks. Prior experience, especially international experience, both business and non-business related, provides the entrepreneur with various information and knowledge. This knowledge coupled with new observations and information can take on new meaning and transform into a new value. Knowledge building is a dynamic constructivist process that cannot be planned or foreseen. OBV of internationalisation builds on Hayek's view of new knowledge construction (Hayek, 1945). Opportunity development in the light of that theory is a creative process in which the entrepreneur develops new ideas by recombining dispersed bits of incomplete knowledge that is spread among people, places and time, in novel ways that serve to create new value.

The second factor of information acquisition is social ties. It is an obvious observation that people gain access to information through interactions with other people. The structure of entrepreneurs' social networks determines what kind of information they receive, in terms of both quantity and quality. The strength of their social ties and their intensity will also determine the speed of the receipt of that information. Much of the important information for international business activity, such as information about locations, market gaps, business environment in various countries or sources of capital, is likely to be spread across a variety of people. Ties to a variety of different people enhances opportunity discovery since diversity of information is unlikely to occur in homogenous networks (Aldrich, 1999). This line of thought is strongly supported by relational theory of firm, which posits networks as strategic assets that enhance the firm's various capabilities (Kreiser, 2011). The formation and utilization of external networks leads to competitive advantage by providing entrepreneurs with an expanded resource base, and wider opportunities for learning. Authors Adler and Kwon (2002) found that networks provide firms with greater access to information and 
improve the quality, relevance and timeliness of that information. An extensive social resource base that allows entrepreneurs to discover opportunities more quickly through their network of relationships appears to be critical for firm internationalisation, taken the limited durability of opportunities. In the context of firm internationalisation, network range stands out as a key feature of established networks. Network range refers to the number of unique knowledge pools (networks) with which the entrepreneur is directly connected (Kreiser, 2011). The more these pools are diverse and set in different national settings, the better.

In order to develop an opportunity in his mind, the entrepreneur has to combine and transform the possessed information in new ways. Differences in cognitive processing among people can influence this transformation process and thus individual propensity to identify opportunity. Cognitive processes play a critical role in transforming the acquired knowledge and experience into a global mindset. Some people are better than other at understanding causal links, categorizing information or have a bigger imagination.

Shane (2003) depicted four broad categories underlying the cognitive abilities critical in opportunity recognition: intelligence, perceptive ability, creativity and not seeking risks. The author quotes studies which suggest that differences among people in their intellectual capacity influence their likelihood of opportunity discovery. A person's general intelligence measured by the IQ is correlated in numerous longitudinal studies with the discovery of more valuable opportunities. Perceptive ability is a critical cognitive skill, since opportunity discovery always involves identification, absorption and analysis of information. Similarly, since opportunities rely on novel solutions to open-ended questions another critical skill, is creativity. Shane quotes ample research which confirms that creativity is a cognitive ability, which enhances the chance of opportunity discovery. The fourth component of important cognitive abilities listed by Shane is not seeing risks. This property of individuals refers to the interpretation of information. Some people in new information and new ideas will mainly see risks, others will mainly see opportunities. Environmental changes and uncertainty evoke panic in some people, while excitement in others. Opportunity discovery cannot be stifled by risk aversion.

People exhibiting the possession of these four fundamental cognitive properties, possess or can develop a global mindset, which is the critical cognitive structure in international contexts. Global mindset is a cognitive individual-level meta-structure which "combines an openness to and awareness of diversity across cultures and markets with a propensity and ability to synthesize across this diversity" (Gupta \& Govindarajan, 2002, p. 117). According to Bowen and Inpken (2009, p. 241), individuals who possess a global mindset, (1) are capable of perceiving, analysing, and decoding the global operating environment, (2) can accurately identify effective managerial actions in the global operating environment, and (3) possess the behavioural flexibility and discipline to act appropriately.

Since a global mindset is a cognitive ability involving absorption and transformation of information, it appears critical to the process of opportunity identification. Global mindset is built on intellectual, psychological and social capital building blocks that take time to develop and constantly evolve with time as the entrepreneurs experience and relationships change. It is just to assume therefore, that individual's opportunity 
recognition being determined to much extent by a global mindset, is often a long-term process that can be traced back to prior knowledge and experiences, factors associated in research with shaping cognitive skills (Mitchell et al., 2002). Numerous prior events determine the patterns of persons' cognitive processes.

Figure 1 synthesizes the above discussion and presents a holistic perspective on opportunity antecedents in a firm internationalisation context. In short, new ideas start with prior knowledge and new information often acquired through networks. Cognition processes coupled with global mindset will enhance the capability of the entrepreneur to understand international markets and can transform various sources of knowledge into new ideas. Therefore diversified experiences and rich networks coupled with diverse cognitive abilities (including a global mindset) of the entrepreneur can enhance international market awareness and opportunity alertness, which may result in the identification or creation of internationalisation opportunity.

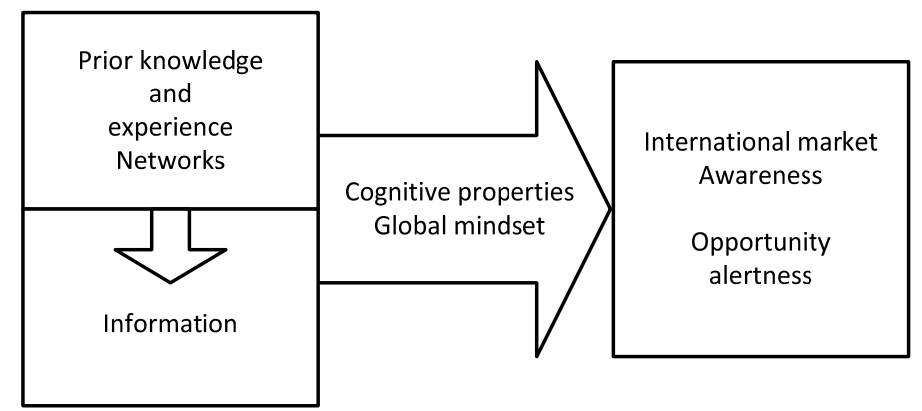

Figure 1. Antecedents of opportunity in firm internationalisation context Source: own evaluation.

The model indicates that opportunity antecedents are interconnected and all necessary to influence new opportunity recognition. All of the variables of the model differ from one individual to another. Based on their earlier experience, individual cognitive properties and social ties, some entrepreneurs can acquire, utilize and process data on market changes across borders quicker than others. They can therefor make quicker decisions about their firm' internationalisation and receive greater profits.

\section{Feedback Effect of Entrepreneurial Learning}

Starting any new business undertaking, especially that of international scope, is based on a number of assumptions that can be tested only by experience. This dynamic process of experimentation and testing assumptions can be referred to as entrepreneurial learning (Cope, 2005). Erdelyi (2010) argues that entrepreneurial learning has two branches: one that involves personal learning and another that involves collective learning. Personal learning focuses on the individual that constitutes the cognitive mechanisms for identifying entrepreneurial business opportunities and making decisions about them, while collective learning arises from the interaction of individuals within a firm or within an ecosystem. And so entrepreneurial learning hits upon a dichotomy between the individual and the networks they are a part of. The relationships the entrepreneur has, both internal and external to the startup, seem to determine the behaviours he/she 
learns, the opportunities he/she can recognize, and the opportunities he/she can act upon.

At the level of the individual entrepreneur, learning can happen twofold, by (i) repetition of efficient practices or (ii) replacement of incorrect knowledge and practices with new ones based on negative feedback or new information. Cope (2005) looked at critical learning events such as significant successes or failures and found out that both of these can impact substantially the entrepreneur's learning process. Some authors suggest that entrepreneurs can learn more from failure than form success, since the first can alert entrepreneurs of incorrect assumptions and beliefs, while positive outcomes lead entrepreneurs to persist with their selected course of action (Petkova, 2009). Discrepancies between expectations and outcomes often occur in entrepreneurial settings and when coupled with deep cognitive processes, they can trigger learning. Because international entrepreneurs are especially involved in experimentation in new and often unpredictable environments, they are more likely to encounter unexpected outcomes (Petkova, 2009). This would suggest that lack of failure may restrict individuals from exploring alternatives, gathering new information and knowledge and looking for new opportunities. Failure situations might therefore lead to enhanced learning processes.

At the organizational level, entrepreneurial learning occurs as a result of two firmlevel processes: (i) the external acquisition of knowledge-based resources outside of the firm's boundaries and/or (ii) internal integration and exploitation of these knowledgebased resources that creates new knowledge within the firm (Kreiser, 2011). New knowledge acquired within various networks can be recombined by individual firms to revise prior knowledge and create novel solutions. The prerequisites of this process are firm-level motivation to participate in knowledge network exchange and the ability to combine these knowledge resources in a way that creates new value (Grant, 1996). Consequently, entrepreneurial learning in international contexts requires firms to exhibit a readiness to seek, absorb and transform new information and knowledge in diverse international contexts. That firm-level competence is a global mindset. As depicted earlier, a global mindset "combines an openness to and awareness of diversity across cultures and markets with a propensity and ability to synthesize across this diversity" (Gupta \& Govindarajan, 2002, p. 117) and as such appears to be critical to entrepreneurial learning in the context of firm internationalisation.

As outlined above, the existing conceptualization of entrepreneurial learning suggest that three prime factors influence that process: new knowledge, new experience and social networks. We can therefore assume that all antecedents of internationalisation opportunities provide expanded learning opportunities for entrepreneurs and their firms. We can assume that with time, the entrepreneurial learning process may lead to better opportunity recognition and more accurate decisions regarding opportunity exploitation.

\section{Findings - Conceptual Model of OBV of Firm Internationalisation}

Opportunity discovery and exploitation in internationalisation context can take a cyclical path, as suggested below. Opportunities can be either created (Schumpeterian) and involve the creation of new means-ends frameworks or identified (Kirznerian) and optimize the existing means-ends frameworks. Either way, opportunity discovery is 
based on the transformation of knowledge and experience deriving from various social networks into new ideas, and involves various cognitive abilities, which in the context of internationalisation sum up to form a global mindset. Through the process of entrepreneurial learning the process of opportunity discovery can be strengthened, taken the entrepreneur and the firm exhibit a global mindset. Entrepreneurs learn from prior decisions, construct new knowledge, strengthen their global mindset and expand their networks. Entrepreneurial learning introduces a loop relationship tying prior experience to future behaviour, moving the entrepreneur to higher levels of international awareness and accuracy in opportunity identification. Entrepreneurial learning affects the entrepreneur's ability to develop and expand knowledge and ideas over time and thereby develop better and more diverse opportunities (Chandra et al., 2012).

All of the processes described in the study concern a certain opportunity space, which has been defined for the purpose of this study as the pool of potential opportunities which are identified by the entrepreneur and are possible to exploit. As entrepreneurs acquire new knowledge, tap into new networks and develop a stronger global mindset, they seek new geographical and consumer markets and the pool of identified potential opportunities grows. Therefore the process of entrepreneurial learning can expand the opportunity space, since new knowledge and experience expands the horizons of international opportunity recognition. Figure 2 presents the cyclical process of opportunity discovery based on the feedback effect provided by entrepreneurial learning and the process of opportunity space expansion.

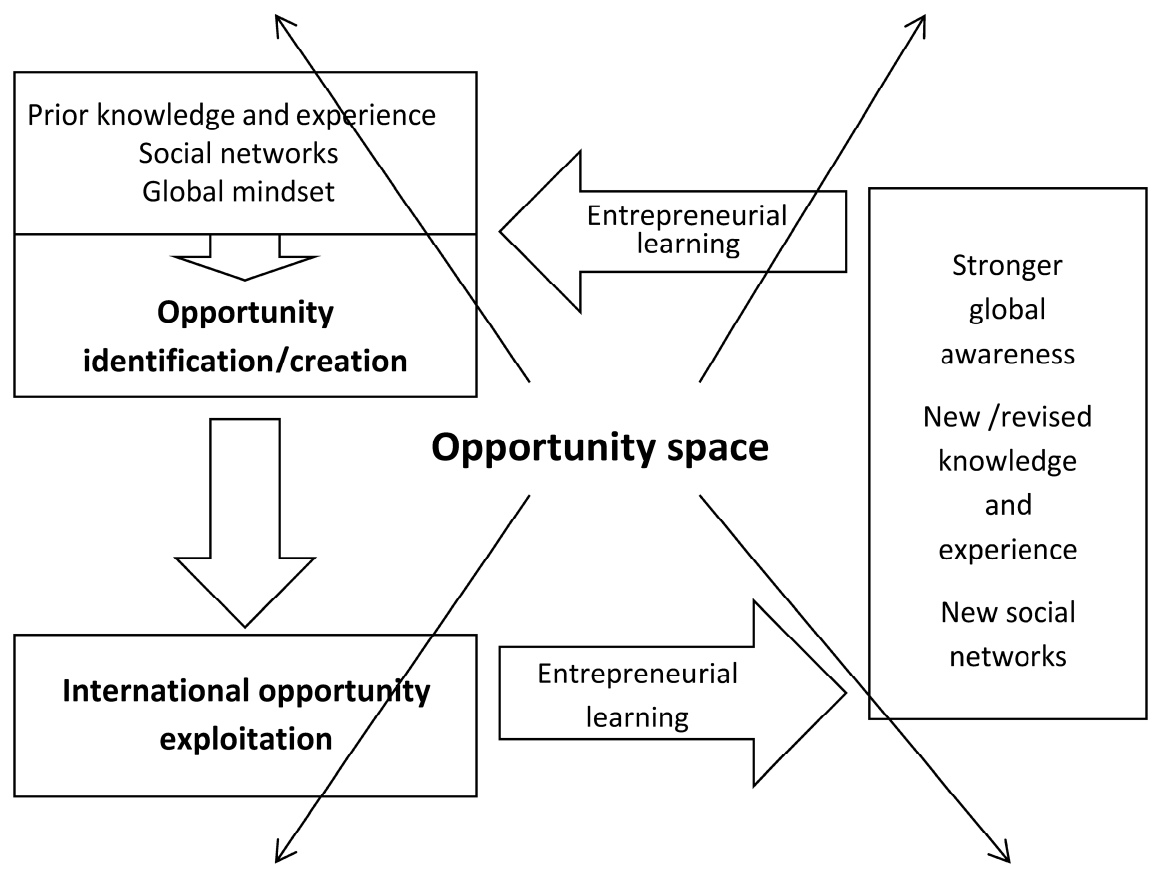

Figure 2. Opportunity-based view of firm internationalisation Source: own evaluation. 
The proposed model draws attention to path-dependency and feedback effects of opportunity exploitation. We can assume that opportunity identification and development is a continuous, cyclical process as one opportunity stimulates other opportunities through exposure to new information, networks and entrepreneurial learning. It shows that the pattern of international opportunity identification and development, as well as commitment to international markets, is cyclical and driven by the feedback effect and by entrepreneurial learning. With time, these processes can significantly enlarge the opportunity space of an entrepreneur. With each "cycle" of opportunity identification or creation, then exploitation and learning, the opportunity space will expand.

Analysing the antecedents and path dependency of international opportunity recognition, provokes some authors to claim that every internationalisation process is set in a period of time longer than we can see and therefore the internationalisation is, in fact, gradual and evolutionary (Chandra et al., 2012). This observation may not be obvious when adapting a strictly firm perspective without looking deeper at the antecedents and entrepreneurial learning cycle of the internationalisation decision. We can assume that many opportunities take long to develop, they grow over time through prior experiences of the entrepreneur. Finally, prior successes and failures, abundant social ties and a strong global mindset might result in a born-global venture. Therefore what by some might be referred to as born global type on internationalisation, in fact, might be a process which goes back in time and may not be that revolutionary.

\section{CONCLUSIONS}

This study hopes to contribute to the discussion devoted to opportunity-based approach of firm internationalisation. It synthesizes fragmented pieces of research on international entrepreneurship, mainstream entrepreneurship and entrepreneurial learning theory and proposes a model of OBV of firm internationalisation.

It refers to earlier findings that firms with a strong entrepreneurial commitment perceive new opportunities more quickly, and their proactive character and their will to take risks facilitate the exploitation of these opportunities. Entrepreneurial firms strive on opportunities and international markets are a natural centre of their attention, as they present new and/or different opportunities than their home country. Studies have shown that entrepreneurial orientation positively influences the firm's propensity and speed to internationalize its activities (Zahra \& Gravis, 2005; Ripolles-Melia et al., 2007; Żur, 2014). Internationalisation as response to entrepreneurial opportunity occurs in various modes, following the opportunity-based contingency approach. As noted by authors, successful internationalisation is not a question of rational and planned approach, but a pragmatic approach in terms of seeking and taking entrepreneurial business opportunities" (Wach \& Wehrmann, 2014; Wach, 2014). Therefore an entrepreneurial lens is relevant as it turns attention to the formation of international ventures in new and existing firms through the exploitation of opportunities. The study synthesizes the complexities inherent to the phenomena of entrepreneurial opportunity and proposes a new research framework.

The proposed model exposes the role of time in international opportunity development, suggesting that opportunity recognition is a path dependent self- 
reinforcing cyclical process. It incorporates antecedents of opportunities and cognitive process that lead to opportunity recognition, and emphasizes the role of global mindset on both individual and firm level. The proposed research framework brings together state-of-the-art research and extends it by providing a deeper understanding of the feedback effect of entrepreneurial learning, as well as highlighting the progressive nature of opportunity space. Hopefully, the model can serve as a useful lens for hypotheses formulation and testing within the research domain of firm internationalisation determinants.

\section{REFERENCES}

Adler, P.S., \& Kwon, S.W. (2002). Social capital: Prospects for a new concept. Academy of Management Review, 27(1), 17-40.

Aldrich, H. (1999). Organizations evolving, London: Sage Publications.

Autio, E., Sapienza, H.J., \& Almeida, J.G. (2000). Effects of age at entry, knowledge intensity and imitability on international growth. Academy of Management Journal, 43(5), 909-924.

Bowen, D., \& Inkpen, A. (2009). Exploring the role of "Global Mindset" in leading change in international contexts. The Journal of Applied Behavioral Science, 45(2), 239-260.

Casillas, J.C., \& Acedo, F.J. (2013). Speed in the Internationalization Process of the firm. International Journal of Management Reviews, 15(1), 15-29.

Casson, M. (1982). The entrepreneur, Totowa, NJ: Barnes \& Noble Books.

Chandra, Y., Styles, C., \& Wilkinson, I.F. (2009). The Recognition of First Time International Entrepreneurial Opportunities: Evidence from Firms in Knowledge-Based Industries. International Marketing Review, 26 (1), 30-61.

Chandra, Y., Styles, C., \& Wilkinson, I. (2012). An opportunity-based View of Rapid Internationalization. Journal of International Marketing, 20(1), 74-102.

Cope, J. (2005). Toward a dynamic learning perspective of entrepreneurship. Entrepreneurship Theory and Practice, 29(4), 373-397.

Daszkiewicz, N., \& Wach, K. (2012). Internationalization of SMEs: Context, Models and Implementation. Gdańsk: Gdańsk University of Technology.

Daszkiewicz, N., \& Wach, K. (2014). Motives for Going International and Entry Modes of Family Firms in Poland. Journal of Intercultural Management, 6(2), 5-18.

Erdelyi, P. (2010). The Matter of Entrepreneurial Learning: A Literature Review. In: International Conference on Organizational Learning, Knowledge and Capabilities (OLKC). Conference Papers, Northeastern University, Boston, MA, USA. (Official URL: http://www.cba.neu.edu/olkc2010/).

Grant, R.M. (1996). Toward a knowledge-based theory of the firm. Strategic Management Journal, 17(2), 109-122.

Hayek, F.A. (1945). The Use of knowledge in Society. American Economic Review, 35(4), 519-530.

Jones, G, \& Butler, J. (1992). Managing internal corporate entrepreneurship: an agency theory perspective. Journal of Management, 18(4), 733-749.

Gupta, A.K., \& Govindarajan, V. (2002). Cultivating a global mindset. Academy of Management Executive 16(1), 116-126.

Kirzner, I. (1973). Competition and Entrepreneurship. Chicago: University of Chicago Press. 
Kirzner, I. (1997). Entrepreneurial discovery and the competitive market process: an Austrian approach. Journal of Economic Literature, 35(1), 60-85.

Kreiser, P.M. (2011). Entrepreneurial Orientation and Organizational Learning; The Impact of Network Range and Network Closure. Entrepreneurship Theory and Practice, 35(5), 10251050.

$\mathrm{Li}, \mathrm{J.}$ (2013). The internationalization of entrepreneurial firms from emerging economies: The role of institutional transitions and market opportunities, Journal of International Entrepreneurship, 11(2), 158-171.

Lu, J.W., \& Beamish, P. W. (2001). The internationalization and performance of SMEs. Strategic Management Journal, 22, 565-686.

Mitchell, R.K., Busenitz L., Lant T., McDougall P. P., Morse E. A, \& Smith J. B. (2002). Toward a Theory of Entrepreneurial Cognition: Rethinking the People Side of Entrepreneurship Research. Entrepreneurship Theory and Practice, 27(2), 93-104.

Petkova, A.P. (2009). A theory of entrepreneurial learning from performance errors. International Entrepreneurship Management Journal, 5(4), 345-367.

Pierścionek, Z. (2011). Zarzqdzanie strategiczne w przedsiębiorstwie, Warszawa: PWN.

Ripolles-Melia, M, Menguzzato-Boulard, M, \& Sanchez-Peinado, L. (2007). Entrepreneurial orientation and international commitment. Journal of International Commitment, 5(3-4), 6583.

Sarasvathy, S.D., Dew, N., Velamuri, S.R., \& Venkataraman, S. (2010). Three views of entrepreneurial opportunity. In Handbook of entrepreneurship research (pp. 77-96). New York: Springer.

Schumpeter, J. (1934). Capitalism, Socialism, and Democracy. Harper \& Row, New York.

Shane, S. (2003). A General Theory of Entrepreneurship, Cheltenham, UK: Edward Elgar.

Shane, S., \& Venkataraman, S. (2000). The promise of entrepreneurship as a field of research. Academy of Management Review, 25(1), 217-226.

Stevenson, H.H., \& Jarillo-Mossi, J.C. (1986). Preserving Entrepreneurship as Companies Grow. Journal of Business Strategy, 7(1), 10-34.

Styles, C., \& Seymour R.G. (2006). Opportunities for Marketing Researchers in International Entrepreneurship. International Marketing Review, 23(2), 126-45.

Venkataraman, S., Dew, N., \& Forster, W.R. (2012). Reflections on the 2010 AMR Decade Award: Wither the Promise? Moving Forward with Entrepreneurship as a Science of the Artificial. Academy of Management Review, 37(1), 21-33.

Wach, K. (2014). Familiness and Born Globals: Rapid Internationalisation among Polish Family Firms. Journal of Intercultural Management, 6(3).

Wach, K \& Wehrman, C. (2014). Entrepreneurship in International Business: International Entrepreneurship as the Intersection of Two Fields. In: A.S. Gubik, \& K. Wach, (Eds.), International Entrepreneurship and Corporate Growth in Visegrad Countries (pp. 9-22). Miskolc: University of Miskolc.

Welch, L. \& Luostarinen, R.K. (1988). Internationalization: evolution of concept. Journal of General Management, 14(2), 36-64.

Zahra, S.A., Ireland, R.D., \& Hitt, M.A. (2000). International Expansion by New Venture Firms: International Diversity, Mode of Market Entry, Technological Learning, and Performance. Academy of Management Journal, 43(5), 925-50.

Zahra, S.A., \& Garvis, D.M. (2000). International corporate entrepreneurship: the moderating effect of international environment hostility. Journal of Business Venturing, 15(5), 469-492. 
Zahra, S.A., \& Wright, M. (2011). Entrepreneurship's Next Act. Academy of Management Perspectives, 25(4), 67-83.

Żur, A. (2014). Corporate Entrepreneurship as an Facilitating Factor in the Rapid Internationalization of firms. The Case of Nowy Styl Group. In: B. Knezevic \& K. Wach, (Ed.), International Business from the Central European Perspective (pp. 83-96). Zagreb: University of Zagreb.

\title{
Author
}

\section{Agnieszka Żur}

Assistant Professor of Entrepreneurship of the Department of Entrepreneurship and Innovation at the Faculty of Economics and International Relations of the Cracow University of Economics (Poland). PhD in management (corporate entrepreneurship). Her current research interests include social entrepreneurship and socially engaged teaching and learning. Author of publications on corporate entrepreneurship and social entrepreneurship. Extensive experience in entrepreneurship and management teaching. Certified trainer and academic OxCam tutor. Member of Academy of Management since 2010. Guest lecturer for Grand Valley State University (Grand Rapids, USA), Western Michigan University (Kalamazoo, USA), Durham University and Luton University (Great Britain), Sodertorn University (Stockholm, Sweden).

\author{
Correspondence to: \\ Agnieszka Żur, PhD \\ Cracow University of Economics \\ Faculty of Economics and International Relations \\ Department of Entrepreneurship and Innovation \\ 31-510 Kraków, ul. Rakowicka 27 \\ zura@uek.krakow.pl
}

\section{Acknowledgements and Financial Disclosure}

The article came into being within the statutory research project no. 121/WE$\mathrm{KPI} / 03 / 2014 / \mathrm{S} / 4317$ entitled "Entrepreneurial and Innovation Processes as Catalyst and Stabilizers of Business Internationalisation" coordinated by $\mathrm{K}$. Wach and financed by the Ministry of Science and Higher Education of the Republic of Poland with the funds allocated to development of research potential of the Faculty of Economics and International Relations of the Cracow University of Economics.

\section{Copyright and License}

This article is published under the terms of the Creative Commons Attribution - NonCommercial - NoDerivs (CC BY-NC-ND 3.0) License http://creativecommons.org/licenses/by-nc-nd/3.0/ 
